\title{
Penerapan Teknik Mind Mapping Untuk Meningkatkan Keterampilan Menulis Teks Eksplanation
}

\section{Sing $\mathbf{S}^{1 *}$, Kartini $\mathbf{N}^{2}$, Saputra I.N.P.H ${ }^{3}$}

${ }^{123}$ Jurusan Pendidikan Bahasa Inggris Universitas Pendidikan Ganesha

\section{ART I CLE I N F O}

Article history:

Received January 21, 202

Revised February 03, 2021

Accepted April 08, 2021

Available online May 25, 2021

\section{Kata Kunci:}

Keterampilan Menulis Mind mapping, Eksplanation teks

Keywords:

Writing skill, Eksplanation text and mind mapping

\section{A B S T R A K}

Penelitian ini bertujuan untuk meningkatkan keterampilan menulis teks Eksplanation siswa kelas XI IPS 2 SMA Negeri 4 Singaraja tahun pelajaran 2018/2019 dengan menggunakan teknik Mind Mapping. Penelitian ini adalah Penelitian Tindakan Kelas, dengan menggunakan prosedur Kemmis dan Taggart yaitu; planning (perencanaan), action (tindakan), observation (pengamatan), dan reflection (refleksi).

Teknik pengumpulan data dalam penelitian ini dilakukan melalui observasi dan test. Data yang diperoleh selama proses penelitin ini kemudian dianalisis secara deskriptif kualitatif dan kuantitatif. Pada bagian observasi terdapat 3 aspek yang di amati yaitu, ranah Kongnitif, ranah Afektif dan ranah Psikomotor. Hasil observasi ranah kongnitif setiap siklusnya mengalami peningkatan yaitu pre observasi $43,52 \%$, siklus I $74,07 \%$, siklus II 93,52\% dan mengalami peningkatan sebesar $\mathbf{5 0 \%}$. Ranah affektif juga mengalami peningkatan yaitu pada observasi awal 42,36\%, siklus I 75,69\%, siklus II 90,97\%, peningkatan ranah ini adalah $\mathbf{4 8 , 6 1} \%$. Peningkatan pada ranah Psikomotor yaitu 39,42\% pada observasi awal, siklus I sebesar 74,07\%, siklus II sebesar 90,74\%, peningkatan pada ranah ini sebesar $\mathbf{5 1 , 3 2 \%}$. Test yang dilakukan dalam penelitian ini menunjukan hasil yang baik yaitu terjadi peningkatan hasil disetiap siklusnya. Jumlah siswa yang mencapai KKM setiap siklusnya adalah 14 siswa $(38,89 \%)$ untuk pre-test, 22 siswa $(72,22 \%)$ untuk Post-test I dan 31 siswa $(86,11 \%)$ untuk post-test II. Nilai rata-rata siswa tiap siklusnya menunjukan peningkatan yaitu 67,52 pada pre-test, 77,82 post-test I dan 83,02 pada post-test II, data ini menunjukan peningkatan sebesar 15,50. Dari hasil yang diperoleh baik melalui observasi dan tes menunjukan bahwa penggunaan teknik mind mapping terbukti dapat meningkatkan keterampilan menulis peserta diik pada teks eksplanation.

\section{A BS TRACT}

This research was conducted at XI IPS 2 SMA Negeri 4 Singaraja to improve students' writing skill on explanation text by using mind mapping technique in academic year 2018/2019. This research is a classroom action research that implemented Kemis and Taggrat's action research procedures. Those procedures consist of planning, acting, observing and reflecting. The data collection method that used in this research were test and observation. After getting the data, the data would be analyzed by using descriptive qualitative and quantitative. There were three aspects that observed in this research they are cognitive aspect, affective aspect and psychomotor aspect. The result of the first aspect in each cycle show the significant improvement that is in pre observation it was 43,52\%, 74,07\% for the first cycle and the second cycle was $93,52 \%$. From that data, the improvement on the first cycle is $50 \%$. In pre observation on affective aspect there were $42,36 \%$ improvement, and then the improvement in first cycle is $75,69 \%$ while in the last cycle the improvement of affective aspect is $90,97 \%$, it means that the improvement on that aspect was $48,61 \%$. On the last aspect of the observation phase was psychomotor aspect, the data from that aspect in pre observation was 39,42\%, 74,07\% for the first cycle and 90,74\% for the last cycle. the improvement of this aspect was 51,32\%. The data from test also has the significant improvement. Based on the test's result the improvement of the result is $67,52 \%$ for the pre-test, $77,82 \%$ for the post test I and $83,02 \%$ for the second Post-test.

\section{Pendahuluan}

Pendidikan dan pengajaran adalah suatu proses yang sadar tujuan. Tujuan dapat diartikan sebagai suatu usaha untuk memberikan rumusan hasil yang diharapkan siswa setelah melaksanakan pengalaman belajar (Sadirman, 2004). Tercapai tidaknya tujuan pengajaran salah satunya adalah terlihat dari prestasi belajar yang diraih siswa. Dengan prestasi yang tinggi, para siswa mempunyai indikasi berpengetahuan yang baik (Pratama, Firman and Neviyarni, 2019). Dalam era globalisasi ini bahasa mempunyai peran yang sangat penting, terlebih fungsi bahasa sebagai alat komunikasi, salah satu bahasa yang harus di kuasai adalah Bahasa Inggris, karena Bahasa Inggris merupakan bahasa internasional dan dijadikan sebagai alat untuk berkomunikasi baik lisan maupun tulisan. Berkomunikasi adalah memahami dan mengungkapkan informasi, pikiran, perasaan, dan mengembangkan ilmu pengetahuan, teknologi, dan budaya. Kemampuan berkomunikasi dalam pengertian yang utuh adalah kemampuan berwacana, yakni

Copyright (C) Universitas Pendidikan Ganesha. All rights reserved. 
kemampuan memahami dan menghasilkan teks lisan atau tulis yang direalisasikan dalam empat keterampilan berbahasa, yaitu mendengarkan, berbicara, membaca dan menulis. Keempat keterampilan inilah yang digunakan untuk menanggapi atau menciptakan wacana dalam kehidupan bermasyarakat. Oleh karena itu, mata pelajaran Bahasa Inggris diarahkan untuk mengembangkan keterampilan keterampilan tersebut agar lulusan mampu berkomunikasi dan berwacana dalam Bahasa Inggris pada tingkat literasi tertentu (Maryanto and Wulanata, 2018).

Bahasa merupakan alat komunikasi yang memegang peranan penting dalam kehidupan. Dengan menggunakan bahasa, seseorang dapat berinteraksi dengan manusia lain, mengekspresikan diri, mengungkapkan perasaan, menyampaikan ide, informasi maupun gagasan serta menyebarluaskan ilmu pengetahuan. Bahkan, melalui ragam bahasa tulis maupun lisan, bahasa dapat berperan menjadi pengantar yang paling efektif dan efisien dalam dunia pendidikan. Kemampuan dan keterampilan berbahasa dapat dilatih dan kemampuan dan keterampilan berbahasa memiliki peran penting dalam dikembangkan secara berkesinambungan dengan pembinaan sedini mungkin. Karena mengembangkan aspek-aspek kognitif, afektif dan psikomotorik sebagai penunjang keberhasilan siswa di masa yang akan dating (Sudrajat and Herlina, 2015). Bahasa mempunyai peranan yang penting dalam pengembangan aspek intelektual, sosial dan emosional siswa. Fungsi bahasa tidak hanya sebagai subyek atau sebuah mata pelajaran tetapi juga sebagai alat siswa untuk meng ekspresikan ide atau pemikiran dan perasaan mereka dalam kehidupan se hari-hari baik di lingkungan masyarakat atau di lingkungan sekolah. Maka, setelah mempelajari bahasa, siswa diharapkan memiliki beberapa ke mampuan khususnya kemampuan ber bicara yang akan mampu membuat mereka berkomunikasi dengan baik dan benar. Terlebih, bahasa adalah sebuah sistem yang diciptakan oleh manusia untuk berkomunikasi (Kurikulum 2004:35). Definisi ini menunjukan bahwa semua orang membutuhkan bahasa untuk berkomunikasi dalam rangka penyampaian ide, gagasan serta perasaan mereka kepada lawan bicara (Ramdhan, 2017).

Pembelajaran Bahasa Inggris adalah salah satu mata pelajaran yang sangat penting untuk di pelajari disemua jenjang pendidikan. Hal ini dikarenakan bahasa inggris menjadi salah satu mata pelajaran yang diujikan pada Ujian Nasional. Selain karena alasan tersebut, bahasa Inggris adalah salah satu bahasa yang digunakan oleh sebagian populasi manusia di dunia ini. Hal ini dikarenakan segala bidang kehidupan mulai dari ilmu pengetahuan dan teknologi sampai pada kehidupan sosial setiap orang di era globalisasi ini menggunakan bahasa inggris sebagai alat untuk berkomunikasi baik secara lisan maupun tulisan. Pembelajaran bahasa Inggris menekankan pada pemerolehan empat keterampilan berbahasa. Keempat keterampilan tersebut adalah membaca, mendengar, berbicara dan menulis. Hal ini sejalan dengan apa yang diungkapkan oleh (Tarigan, 2008), yang menyatakan bahwa terdapat empat keterampilan berbahasa yang harus dikuasai oleh peserta didik, antara lain: (1). keterampilan menyimak/mendengarkan (listening skills), (2). Keterampilan berbicara (speaking skills), (3). Keterampilan membaca (reading skills) dan (4). Keterampilan menulis (writing skills). Oleh karena itu tujuan akhir pembelajaran bahasa inggris pada kurikulum 2013 adalah bagaimana peserta didik menggunakan keterampilan bahasa tersebut untuk berkomunikasi dengan baik dan benar secara lisan dan tulisan.

Dari keempat keterampilan berbahasa yang telah disebutkan di atas, keterampilan menulis menjadi salah satu keterampilan yang harus dikuasai oleh peserta didik. Pembelajaran menulis pada Kurikulum 2013 terdapat pada KI 4 (Kompetensi Inti ke-4) yaitu mencoba, mengolah, dan menyaji dalam ranah konkret (menggunakan, mengurai, merangkai, memodifikasi, dan membuat) dan ranah abstrak (menulis, membaca, menghitung, menggambar, dan mengarang) sesuai dengan yang dipelajari di sekolah dan sumber lain yang sama dalam sudut pandang/teori (Kemendikbud, 2014). Menulis berarti kita menyampaikan gagasan, ide serta pikiran kita melalui tulisan. Menulis bukan sekedar menuangkan lambang-lambang atau tanda-tanda yang bisa dibaca tetapi tulisan tersebut harus bisa dipahami dan dimengerti serta memiliki makna. Hal ini senada dengan apa yang di ungkapkan (Tarigan, 2008) menurutnya menulis ialah menurunkan atau melukiskan lambang-lambang grafik yang menggambarkan suatu bahasa yang dipahami oleh seseorang, sehingga orang-orang lain dapat membaca lambang-lambang grafik tersebut kalau mereka memahami bahasa dan gambaran grafik itu.

Secara umum kompetensi bahasa Inggris di SMA/MA dan SMK/MAK adalah kemampuan berkomunikasi baik secara lisan maupun tulisan dalam tiga jenis teks, (1) interpersonal, (2) transaksional, dan (3) fungsional. Gerot dan Wignell (1995: 212) menjelaskan secara singkat tentang teks eksplanasi yang berisi pembentukan suatu proses atau apa yang dikerjakan dari gejala alam atau sosial budaya. Dalam bukunya yang berjudul "Teks Types In English", Anderson (1997: 80-81) mengungkapkan teks eksplanasi adalah suatu jenis teks yang mengungkapkan bagaimana dan mengapa sesuatu itu terjadi. Tujuan dari teks eksplanasi tersebut adalah untuk mengungkapkan setiap langkah dari proses bagaimana dan untuk memberi alasan mengapa. Untuk hal yang lebih luas, biasanya teks eksplanasi menjelaskan 
tentang bagaimana sesuatu itu terjadi, mengapa sesuatu itu terjadi, mengapa suatu benda itu sama atau berbeda, dan bagaimana untuk memecahkan suatu masalah.

Teks Eksplanasi pada hakikatnya merupakan teks yang menjelaskan proses. Proses tersebut dapat terjadi secara alamiah, baik yang berkaitan dengan fenomena (gejala) alam maupun fenomena sosial budaya. Pada umunya, teks eksplanasi dibentuk dengan struktur (susunan), yaitu pernyataan umum, penjelasan, dan penutup atau simpulan (Wahono, 2013). Untuk menghasilkan sebuah teks ekplanation yang baik dan benar perlu ada pemahaman tentang teks tersebut dan kemampuan dalam hal menulis. Kombinasi antara pemahaman dan kemampuan menulis ini membuat proses menulis teks tersebut bukanlah hal yang mudah untuk dilakukan. Hal ini terlihat pada hasil tulisan siswa kelas XI IPS 2 SMA Negeri 4 Singaraja yang ditunjukan lewat pre-test yang diberikan oleh penulis. Dari hasil tes awal tersebut banyak siswa yang nilainya dibawa KKM. Dari jumlah keseluruhan 36 siswa yang mengikuti pre-test tersebut pada tanggal 28 maret 2019 menunjukan sebanyak 22 siswa atau sekitar 61,11\% yang nilainya dibawa KKM. Sedangkan 14 atau sekitar 38,89\% siswa lainya mampu menuliskan teks tersebut dengan nilai yang cukup memuaskan. Dari hasil ini terlihat bahwa sebagian siswa masih mengalami masalah dalam menulis teks tersebut.

Selanjutnya pada hasil analisa yang dilakukan lewat observasi awal peneliti menunjukan beberapa hal yang menjadi permasalahn bagi para siswa. Permasalahan awanya adalah siswa mengalami kesulitan dalam memulai sebuah paragraph (general statement). Siswa mengalami kesulitan dalam hal bagaimana memulai sebuah tulisan yang baik berkaitan dengan teks yang diminta. Terlalu banyak memakan waktu untuk memutuskan membuat paragraf awal karena kurangnya informasi dan pemahaman siswa terkait topic yang diminta. Selanjutnya pada tahapan mengembangkan ide yang mereka miliki, siswa mengalami masalah dalam mengembangkan ide-ide yang mereka miliki terkait topik yang dibahas. Hal ini ditunjukan lewat tidak beraturanya tulisan mereka, siswa sering mengalami loncatan pada saat menuliskan beberapa rangkaian proses (sequences of explanation). Siswa tidak memiliki kemampuan untuk menyusun ide-ide dalam sebuah rangkaian yang runtut sehingga mudah dipahami. Mereka seperti kehilangan arah saat menulis, hal ini menyebabkan gagasan yang ada pada pikiran mereka tidak dapat tersalurkan dengan baik dan beraturan. Permasalahan lain terdapat pada saat pemilihan kata dan bahasa, siswa sering menggunakan kata-kata yang sama dan kata-kata tersebut terus diulang-ulang. Ini menunjukan kurangnya kosakata yang mereka miliki. Selanjutnya siswa masih mengalami masalah pada saat pengembangan kalimat dan tata bahasa serta mekanisme penulisan seperti ejaan, kapitalisasi, dan tanda baca yang mereka digunakan.

Berkaca pada permasalahan yang telah dijelaskan diatas, peneliti mencoba menemukan solusi yang bisa menjawab semua permasalahan tersebut. Menurut (Sukirno, 2009) salah satu upaya untuk meningkatkan mutu pembelajaran menulis di sekolah adalah perbaikan proses pembelajaran menulis.

Untuk meningkatkan kemampuan menulis peserta didik di kelas XI IPS 2 SMA negeri 4 Singaraja tahun ajaran 2018/2019, penulis memilih teknik Mind Mapping sebagai strategi untuk memecahkan permasalahan yang dihadapi oleh peserta didik. Teknik mind map merupakan salah satu teknik yang dapat memotivasi siswa lebih berimajinasi, kreatif dan terampil dalam menuliskan sebuah ide yang nantinya akan membuat siswa mudah dalam menulis teks eksplanasi. Menurut (DePorter, Bobbi, Hernacki, 2013) pendekatan peta pikiran atau mind map merupakan pendekatan keseluruhan otak yang membuat kita mampu membuat catatan yang menyeluruh dalam satu halaman. Dengan menggunakan citra visual dan perangkat grafis lainnya, mind map akan memberikan kesan yang lebih dalam. Adapun kelebihan atau manfaat menggunakan metode mind mapping menurut Tony Buzan (2006) Metode Mind Mapping (peta pikiran) akan meningkatkan daya hafal dan motivasi belajar siswa yang kuat, serta siswa menjadi lebih kreatif.

\section{Metode}

Jenis Penelitian yang digunakan oleh peneliti ialah Penelitian Tindakan Kelas. Penelitian ini dilakukan dalam beberapa siklus sebagai jalan keluar yang ditempuh untuk memecahkan masalah yang ditemukan oleh guru dalam proses pembelajaran di kelas. Prosedur yang digunakan dalam penelitian ini diadaptasi dari Kemmis dan Taggart (2002) yang mempunyai empat tahapan, antara lain: planning (perencanaan), action (tindakan), observation (pengamatan), dan reflection (refleksi). 


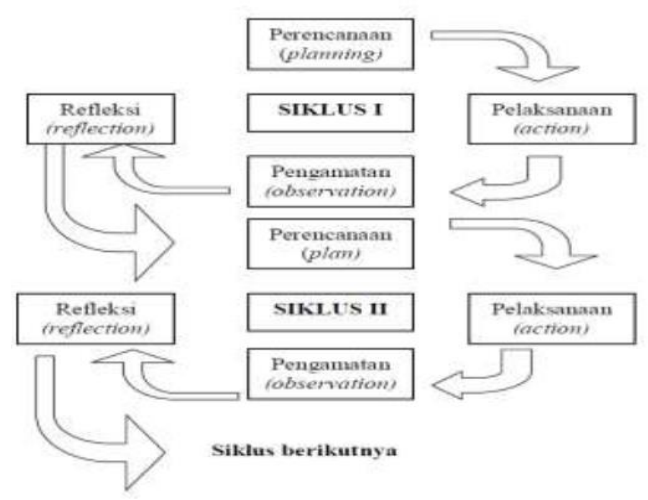

Gambar 1. Alur Pelaksanaan PTK

penelitian ini dilakukan di Kelas XI IPS 2, SMA Negeri 4 Singaraja, pada Semester II Tahun pelajaran 2018/2019. Dengan jumlah siswa sebanyak 36 orang. Objek penelitian ini adalah penggunaan teknik Mind Map untuk meningkatkan keterampilan menulis teks explanation.

Penelitian ini menggunakan dua instrumen atau teknik pengumpulan data yang yang mencakup: Data proses pembelajaran ini diperoleh dari lembar observasi yang dikumpulkan selama proses penelitian berlangsung. Jenis data yang dihasilkan berupa data kualitatif yang merupakan informasi tentang aktifitas siswa. Produk atau hasil belajar siswa diperoleh dari hasil pelaksanaan tindakan atau penerapan teknik Mind Map dalam pembelajaran explanation text. Pengumpulan data ini dilaksanakan melalui penilaian terhadap hasil tulisan siswa tentang explanation text.

Untuk menganalisa data yang akan dikumpulkan, maka peneliti menggunakan dua cara yaitu kuantitatif dan kualitatif. Data yang akan dianalisa dengan cara kualitatif ialah lembar observasi, sedangkan analisa data secara kuantitatif meliputi hasil tes siswa. Penilaian hasil tes menulis siswa dilakukan dengan beberapa prosedur atau langkah perhitungan antara lain sebagai berikut;

a) Menghitung perolehan nilai setiap siswa

b) Menentukan ketuntasan klasikal (Presentase Kelas)

c) Setelah melakukan perhitungan (total score perolehan siswa) maka nilai yang mereka peroleh dikategorikan menjadi dua kriteria yaitu Tuntas dan Tidak Tuntas.

Setelah menentukan ketuntasan peserta didik berdasarkan kategori ketuntasan, maka peneliti melakukan klasifikasi terhadap nilai yang diperoleh dengan menggunakan rentang nilai

\section{Hasil Dan Pembahasan}

Berdasarkan hasil observasi yang dilakukan menunjukan bahwa pada pre observasi presentase ranah kongnitif adalah $43,52 \%$, dan pada observasi kedua yakni pada pelaksanaan tindakan siklus kedua menunjukan $74,07 \%$. Dari hasil tersebut menunjukan penggunaan mind mapping dalam aktivitas belajar peserta didik menulis teks eksplanation mengalami peningkatan sebanyak 30,55\%. Pada observasi terakhir yakni pada siklus kedua hasil observasi menunjukan 93,52\%, hal ini menunjukan peningkatan sebesar 50\%. Hasil ini menunjukan beberapa hal yakni; peserta didik dapat memahami konteks penggunaan mind mapping terhadap teks eksplanation, peserta didik dapat mengajukan atau menyampaikan ide mereka dengan baik serta mereka dapat menjawab pertanyaan guru dengan baik.

Hasil observasi pada ranah afektif mengalami peningkatan yang cukup besar, yakni pada pre observasi sebesar $42,36 \%$ dan pada siklus I sebesar 75,69\%. Hasil ini menunjukan peningkatan sebesar $33,33 \%$. Pada observasi terakhir hasil menunjukan 90,97\%, hasil ini menunjukan terdapat peningkat dari siklus sebelumnya yakni 48,61\%. Observasi pada ranah afektif ini merujuk pada empat point utama yaitu, motivasi belajar, kreatifitas, percaya diri dan bekerja keras. Peningkatan pada empat aspek pengamatan tersebut menunjukan bahwa ada peningkatan kualitas terhadap aktifitas belajar siswa serta respon mereka terhadap penggunaan teknik mind mapping untuk menulis teks eksplanation.

Ranah psikomotor adalah hal terakhir yang diobservasi oleh peneliti. Hasil pre observasi menunjukan 39,42\% dan observasi kedua menunjukan hasil 74,07\%. Hasil ini menunjukan peningkatan sebesar $34,65 \%$. Hasil observasi terakhir menunjukan angka yang cukup besar yaitu 90,74\%. Hasil ini mengalami peningkatan sebesar 51,32\%. Observasi pada ranah Psikomotor ini mencakup tiga hal yakni; memulai sebuah tulisan, mengembangkan ide atau gagasan dengan baik, serta menghasilkan tulisan yang baik berdasarkan kaidah penulisan dan struktur teks dari teks eksplanation.

Berikut hasil observasi terhadap ketiga ranah pada pembelajaran tersebut; 
Table 1. Hasil Peningkatan Observasi

\begin{tabular}{lllllll}
\hline No & $\begin{array}{l}\text { Ranah/aspe } \\
\mathbf{k}\end{array}$ & Observasi awal & $\begin{array}{l}\text { Observasi } \\
\text { siklus I }\end{array}$ & Peningkatan & $\begin{array}{l}\text { Observasi } \\
\text { siklus II }\end{array}$ & $\begin{array}{l}\text { Peningka } \\
\text { tan }\end{array}$ \\
\hline 1 & Kongnitif & $43,52 \%$ & $74,07 \%$ & $30,55 \%$ & $93,52 \%$ & $50 \%$ \\
2 & Afektif & $42,36 \%$ & $75,69 \%$ & $33,33 \%$ & $90,97 \%$ & $48,61 \%$ \\
3 & Psikomotor & $39,42 \%$ & $74,07 \%$ & $34,65 \%$ & $90,74 \%$ & $51,32 \%$ \\
\hline
\end{tabular}

Hasil tes yang dilakukan selama proses penelitian ini menunjukn peningkatan yang signifikan. Hasil pre-test menunjukan total nilai yang dihasilkan oleh seluruh siswa adalah $2.432,4$ atau sekitar $67,57 \%$. Nilai rata-rata kelas adalah 67,52 dengan presentase kelas adalah 38,89\%. Presentase ini masuk dalam kategori kurang. Selanjutnya pada siklus kedua nilai rata-rata post-test siswa adalah 77,82 . Nilai ini mengalami peningkatan dari hasil pre-test yang dilakukan oleh peserta didik sebesar 15,50. Sementara itu total nilai yang diperoleh seluruh siswa adalah $2.801,7$ atau sekitar $77,82 \%$. Nilai ini mengalami peningkatan dari pre-test sebesar 369,3 atau meningkat sebesar 10,25\%. Presentase kelas pada post-test I ini adalah 72,22\%, hasil ini meningkat dari pre-test sebesar 33,33\%. Pada post-test 2 yang dilakukan pada siklus kedua jumlah nilai perolehan seluru siswa adalah 2989, meningkat sebanyak 556,6. Rata-rata nilai peserta didik adalah 83,03 , nilai ini mengalami peningkatan sebesar 15,50 . Presentase kelas pada posttest 2 ini adalah 86,11\%, nilai ini juga mengalami peningkatan sebanyak 47,22\%.

\section{Simpulan}

Berdasarkan Berdasarkan hasil penelitian yang telah diperoleh selama melakukan proses penelitian guna peningkatan keterampilan menulis teks eksplanation menggunakan teknik Mind Mapping yang sudah peneliti laksanakan di kelas XI IPS 2 SMA Negeri 4 Singaraja, maka dapat disimpulkan beberapa hal sebagai berikut:

\section{a) Hasil Observasi}

Aktifitas siswa selama proses pembelajaran menulis teks eksplanation menggunakan teknik mind mapping mengalami peningkatan. Berdasarkan hasil observasi yang dilakukan selama proses pembelajaran, Peserta didik menunjukan keaktif yang sangat besar. Selain aktif dalam proses pembelajaran, peserta didik juga termotivasi melakukan pembelajaran menulis. Peserta didik lebih percaya diri dalam hal mengungkapkan pendapat dan menjawab pertanyaan yang diberikan oleh guru.

Peserta didik mendapatkan pemahaman lebih tentang bagaimana membuat mind mapping dengan kata-kata kunci sehingga dapat dengan mudah mengembangkan teks sesuai dengan topic yang diminta. Dalam hal menulis teks eksplanation peserta didik dapat memulai sebuah teks eksplanation dengan sangat baik, mereka juga dapat menuangkan ide-ide mereka dengan cara mengembangkan tulisan mereka kea rah yang benar dan logis, selain itu peserta didik juga mampu mengorganisir tulisan mereka kedalam struktur teks yang beraturan dengan menggunakan ragam bahasa dan tata bahasa yang baik dan benar.

Hal ini diperkuat dengan hasil observasi yang dilakukan pada tiga ranah aspek yaitu ranah kongnitif, afektif dan psikomotor. Pada ranah kongnitif pada pre test yang semulanya adalah $43,52 \%$ meningkat 30,55\% menjadi 74,07\% pada siklus I. Pada siklus kedua terjadi peningkatan sebesar 50\% menjadi 95,52\%. Pada ranah atau aspek afektif yang diobservasi juga mengalami peningkatan, hasil observasi menunjukan pada pre observasi yang hanya 42,36\% mengalami peningkatan sebanyak 33,33\% pada siklus pertama. Sedangkan pada siklus kedua terjadi peningkatan sebesar 48,61\% menjadi 90,97\%. Aspek berikutnya yang juga diobservasi oleh peneliti adalah ranah Psikomotor. Pada observasi awal hasil menunjukan hanya 39,42\%, pada siklus pertama terjadi peningkatan sebesar 34,65\% menjadi 74,07\%. Pada siklus kedua terjadi peningkatan sebesar 51,32\% menjadi 90,74\%.

b) Hasil test menulis teks eksplanation

Penerapan teknik mind mapping dalam pembelajaran menulis teks dapat meningkatkan keterampilan peserta didik dalam menulis teks eksplanation. Hasil belajar yang ditunjukan dalam tiga kali tes yaitu pre test, post test I dan post test II mengalami peningkatan. Presentase ketuntasan kelas menunjukan hasil yang signifikan yaitu pada pre test sebesar 38,89\% mengalami peningkatan sebanyak $33,33 \%$ menjadi $72,22 \%$ pada post test I. Sedangkan pada post test II mengalami peningkatan sebesar 47,22\% menjadi 86,11\%. Dengan jumlah peserta didik yang mencapai KKM setiap siklusnya adalah 14 siswa (38,89\%), 22 siswa (72,22\%) dan 31 siswa (86,11\%).

Berdasarkan hasil test tersebut maka dapat disimpulkan bahwa penggunaan teknik mind mapping dapat meningkatkan kemampuan menulis peserta didik terutam pada teks eksplanation. 


\section{Daftar Pustaka}

DePorter, Bobbi, Hernacki, M. (2013) Quantum Learning: Membiasakan Belajar Nyaman dan Menyenangkan. Bandung: Kaifa Learning.

Kemendikbud (2014) Pedoman Penyusunan Kurikulum Tingkat Satuan Pendidikan di Sekolah Dasar. Jakarta: Depdiknas.

Maryanto, R. I. P. and Wulanata, I. A. (2018) 'Penggunaan Media Flashcard Untuk Meningkatkan Pengenalan Bentuk Huruf Siswa Kelas I Pada Mata Pelajaran Bahasa Indonesia Di Sekolah Abc Manado', Pedagogia, 16(3), p. 305. doi: 10.17509/pdgia.v16i3.12073.

Pratama, F., Firman, F. and Neviyarni, N. (2019) 'Pengaruh Motivasi Belajar Siswa Terhadap Hasil Belajar Ipa Di Sekolah Dasar', Edukatif: Jurnal Ilmu Pendidikan, 1(3), pp. 280-286. doi: 10.31004/edukatif.v1i3.63.

Ramdhan, V. (2017) 'Pengaruh Penguasaan Kosakata dan Tata Babasa Terhadap Pemahaman Membaca Teks Narasi bahasa Inggris (The influence of the mastery of vocabulary and Grammar Babasa Against reading comprehension Text English Narration)', Deiksis, 09(02), pp. 240-246.

Sudrajat, H. N. and Herlina, H. (2015) 'Meningkatkan Pemahaman Kosakata Bahasa Inggris Melalui Metode Permainan Bingo', JIV-Jurnal Ilmiah Visi, 10(2), pp. 114-121. doi: 10.21009/jiv.1002.6.

Sukirno (2009) Pembelajaran Menulis Kreatif dengan Strategi Belajar Akselerasi. Purworejo: UM Purworejo Press.

Tarigan, H. G. (2008) Menulis Sebagai Suatu Keterampilan Berbahasa. Bandung. Bandung: Angkasa Bandung.

Wahono (2013) Buku guru ilmu pengetahuan alamSMP/MTs kelas VII. Jakarta: Kemendikbud. 